\title{
ANALISIS FAKTOR-FAKTOR YANG MEMPENGARUHI PRODUKSI JAGUNG (Zea mays) DI DESA LOSSO KECAMATAN SAMPAGA KABUPATEN MAMUJU
}

\author{
Analysis of Factors Affecting Corn Production (Zea mays) in Losso Village \\ Sampaga District Mamuju \\ Samsuddin $^{1}$ dan Laode Ferial Gufran ${ }^{2}$ \\ ${ }^{12)}$ Jurusan Agribisnis, Universitas Tomakaka Mamuju, Jl Ir. H Juanda No. 77, Mamuju \\ ${ }^{1 *}$ assyamsaleh@gmail.com, ${ }^{2)}$ ferialgufran@gmail.com
}

\begin{abstract}
ABSTRAK
Tujuan penelitian ini adalah untuk mengetahui faktor-faktor yang mempengaruhi produksi jagung (Zea mays) di Desa Losso Kecamatan Sampaga Kabupaten Mamuju. Metode yang digunakan dalam penelitian untuk mengetahui kebenaran hipotesis dalam penelitian ini adalah metode analisis data regresi linear berganda. Hasil penelitian menunjukkan bahwa variabel luas lahan secara parsial berpengaruh secara signifikan terhadap produksi petani jagung di Desa Losso Kecamatan Sampaga Kabupaten Mamuju karena nilai probabilitasnya 0,000<0,05 dengan hasil uji t sebesar 4,730. Dalam model regresi koefisien $X_{1}$ luas lahan (LL) diperoleh nilai 1,013, dimana setiap penambahan luas lahan sebesar $1 \%$ maka akan terjadi kenaikan hasil produksi sebesar 1,013\% dengan asumsi jumlah modal dan tenaga kerja tetap. Sementara modal tidak berpengaruh secara signifikan terhadap produksi petani jagung. Hal ini dibuktikan dari hasil uji t sebesar (1.168) dengan nilai probabilitas 0,257 koefisien $\mathrm{X}_{2}$ modal (M) sebesar $(0,280)$ yang berarti setiap penambahan modal sebesar $1 \%$ maka akan terjadi kenaikan hasil produksi sebesar $(0,280) \%$, dengan asumsi luas lahan dan tenaga kerja tetap.Variabel tenaga kerja, secara parsial tidak berpengaruh secara positif dan signifikan terhadap produksi petani jagung ditunjukkan dari hasil uji t sebesar 1,303 dengan nilai probabilitas 0,208. Koefisien $X_{3}$ tenaga kerja (TK) sebesar 0,204, dimana setiap penambahan tenaga kerja sebesar $1 \%$ maka akan terjadi kenaikan hasil produksi sebesar $0,204 \%$, dengan asumsi luas lahan dan modal tetap.
\end{abstract}

Kata kunci : jagung, produksi, pengaruh

\section{ABSTRACT}

The purpose of this study was to determine the factors that influence the level of maize production (Zea mays) in Losso Village, Sampaga District, Mamuju Regency. The method used in this study to determine the truth of the hypothesis in this study is the method of multiple linear regression data analysis. The results showed that the variable of land area partially has a significant effect on the production of corn farmers in Losso Village, Sampaga District, Maтuju Regency because the probability value is $0.000<0.05$ with the t test result of 4.730 . In the regression model the coefficient of $X_{I}$ (land area) is obtained a value of 1.013, where each additional land area of $1 \%$, there will be an increase in production yields of $1.013 \%$ assuming the amount of capital and permanent labor. While capital does not have a significant effect on the production of corn farmers. This is evidenced by the results of the $t$ test of (1.168) with a probability value of 0.257.The $X_{2}$ coefficient of capital $(M)$ is $(0.280)$ which means that every $1 \%$ increase in capital will result in an increase in production yields of $(0.280) \%$, with the assumption of fixed land area and labor. The labor variable partially does not have a positive and significant effect on the production of corn farmers as indicated by the t test results of 1.303 with a probability value of 0.208 . The $X_{3}$ coefficient of Labor (TK) is 0.204 , where every $1 \%$ addition of labor, there will be an increase in production output of $0.204 \%$, assuming land area and fixed capital.

Keywords: corn, production, influence

\section{PENDAHULUAN}

\author{
Provinsi Sulawesi Barat memiliki \\ kekayaan alam yang sangat melimpah
}

sehingga membuat Provinsi Sulawesi Barat menjadi salah satu Provinsi yang memiliki potensi sangat besar dalam sektor pertanian. 
Perbal: Jurnal Pertanian Berkelanjutan

Fakultas Pertanian Universitas Cokroaminoto Palopo

Sektor pertanian merupakan salah satu sektor strategis dalam pembangunan Nasional. Perkembangan sektor pertanian khususnya pertanian tanaman pangan, memiliki kaitan erat dengan masalah ketahanan pangan negara.

Berdasarkan data BPS (2016), bebarapa tahun terakhir produksi tanaman pangan Provinsi Sulawesi Barat menurun pada tahun 2016. Produksi Jagung khususnya, jika dibandingkan dengan tahun 2015 produksi jagung mengalami penurunan kurang lebih sebesar 1,09 persen dari 110.665 ton menjadi 100.811 ton. Produksi tanaman jagung di kabupaten Mamuju terus mengalami penurunan dari tahun 2013 sampai dengan 2015. Penurunan produksi pada tahun 2015 terkait dengan penurunan luas panen jagung menjadi 5.706 hektar dengan produksi 27.906 ton, produksi jagung pada tahun 2014 sebesar 28.202 ton dengan luas lahan 5.767 hektar, dibandingkan dengan produksi tahun 2015, terjadi penurunan sebanyak 296 ton. Penurunan produksi jagung terkait dengan penurunan luas panen jagung.

Menurut Rusastra dan Suryadi (2004), tanaman palawija memiliki prospek yang baik untuk dikembangkan karena kecenderungan umum menunjukkan bahwa pendapatan rumah tangga di daerah berbasis non-jagung lebih tinggi, stabil, dan berkelanjutan dibandingkan dengan pendapatan rumah tangga pada daerah tradisional berbasis usahatani jagung.

Jumlah penduduk Kabupaten Mamuju pada tahun 2015 mencapai 265.800 jiwa, terjadi peningkatan jumlah penduduk di bandingkan tahun 2014 (BPS Provinsi Sulawesi Barat, 2016). Peningkatan jumlah penduduk ini akan meningkatkan jumlah kebutuhan pokok terutama kebutuhan akan pangan. Hal ini menyebabkan Kabupaten Mamuju menjadi salah satu daerah potensial untuk pengembangan berbagai macam komoditas pertanian termasuk jagung sebagai bahan pokok untuk memenuhi kebutuhan pangan masyarakat. Desa Losso memiliki potensi lahan yang telah diidentifikasi penggunaannya dan dimanfaatkan oleh masyarakat petani (Tabel $1)$.

Berdasarkan Tabel 1 menunjukkan bahwa daerah Kecamatan Sampaga berpotensi untuk kegiatan budidaya jagung. Pada tahun 2012, realisasi luas panen jagung di Kecamatan Sampaga yaitu sebesar 1.137 hektar dengan produksi 6.358 ton. Adapun tujuan penelitian ini adalah untuk mengetahui faktor-faktor yang mempengaruhi tingkat produksi jagung 
(Zea mays) di Desa Losso Kecamatan Sampaga Kabupaten Mamuju.

Tabel 1. Identifikasi tanaman pangan dan hortikultura di Desa Losso, Kecamatan Sampaga Kabupaten Mamuju

\begin{tabular}{llll}
\hline No. & Jenis Tanaman & Areal $(\mathrm{Ha})$ & Produksi/Hektar $(\mathrm{Kg})$ \\
\hline 1. & Padi Sawah & 200 & 4.500 \\
2. & Jagung & 400 & 4.420 \\
3. & Ubi Kayu & 1,50 & 500 \\
4. & Ubi Jalar & - & - \\
5. & Kacang Tanah & 0.50 & 250 \\
6. & Kacang Hijau & - & - \\
7. & Sayur-sayuran & 4 & 180 \\
\hline
\end{tabular}

Sumber : Data Kantor Desa Losso, 2018

\section{METODE PENELITIAN}

Penelitian ini menggunakan metode penelitian korelasional yaitu penelitian yang menggunakan metode survey dengan teknik korelasional, dengan tiga variabel $\mathrm{X}$ variabel independen yaitu luas lahan $\left(\mathrm{X}_{1}\right)$, modal $\left(\mathrm{X}_{2}\right)$ tenaga kerja $\left(\mathrm{X}_{3}\right)$ dan variabel $\mathrm{Y}$ produksi jagung sebagai variabel dependen (Y). Menurut Sugiyono (2009), populasi adalah jumlah keseluruhan dari satuan-satuan atau individu-individu yang karakteristiknya hendak diteliti.

Populasi dalam penelitian ini adalah keseluruhan petani jagung yang ada di Desa Losso Kecamatan Sampaga Kabupaten Mamuju sebanyak 310 orang. Jumlah keseluruhan anggota kelompok tani yang terdapat di Desa Losso untuk menentukan besarnya sampel digunakan rumus sampel Slovin, yaitu (Sujarweni \& Endrayanto, 2012):

$$
n=\frac{N}{1+N e^{2}}
$$

Ket :

n : Jumlah sampel minimal

$\mathrm{N} \quad$ : Populasi

E : Error margin

Jumlah sampel dalam penelitian ini adalah 23 ditentukan dengan teknik systematic sampling.

\section{Analisis Regresi Linier Berganda}

Metode analisis dalam penelitian ini adalah analisis regresi linier berganda dengan menggunakan bantuan aplikasi SPSS versi 16.0, hubungan secara linear antara dua atau lebih variabel independen $\left(\mathrm{X}_{1}\right.$, $\left.\mathrm{X}_{2}, \ldots \mathrm{Xn}\right)$.

\section{Analisis Determinasi $\mathbf{R}_{2}$}

Analisis determinasi $\mathrm{R}_{2}$ dalam regresi linear berganda digunakan untuk mengetahui persentase sumbangan pengaruh variabel 
Perbal: Jurnal Pertanian Berkelanjutan

Fakultas Pertanian Universitas Cokroaminoto Palopo

independen $\left(\mathrm{X}_{1}, \mathrm{X}_{2}, \ldots \mathrm{Xn}\right)$ secara serentak terhadap variabel dependen $(\mathrm{Y})$.

\section{Uji kofisien regresi secara bersama-sama (Uji F)}

Uji ini digunakan untuk mengetahui apakah variabel independen $\left(\mathrm{X}_{1}, \mathrm{X}_{2} \ldots \mathrm{Xn}\right)$ secara bersama-sama berpengaruh secara signifikan terhadap variabel dependen $(\mathrm{Y})$.

Uji koefisien regresi secara parsial (Uji t)

Uji ini digunakan untuk mengetahui apakah dalam model regresi variabel independen $\left(\mathrm{X}_{1}, \mathrm{X}_{2}, \ldots . \mathrm{Xn}\right)$ secara parsial berpengaruh signifikan terhadap variabel dependen (Y).

Tabel 2. Hasil analisis regresi linier berganda SPPS 16.0

\section{Coefficients $^{\mathrm{a}}$}

\begin{tabular}{|c|c|c|c|c|c|c|}
\hline & & & ardized & Standardized & & \\
\hline & & & & & $\mathbf{t}$ & Sig. \\
\hline & Model & & cients & Coefficients & & \\
\hline & & $\mathrm{B}$ & Std. Error & Beta & & \\
\hline 1 & (Constant) & .267 & .222 & & 1.201 & .245 \\
\hline & Luas Lahan & 1.013 & .214 & 1.093 & 4.730 & .000 \\
\hline & Modal & -.280 & .239 & -.293 & -1.168 & .257 \\
\hline & Tenaga Kerja & .204 & .157 & .169 & 1.303 & .208 \\
\hline
\end{tabular}

a. Dependent Variable: Produksi

Sesuai dengan Tabel 2, maka hasil analisis regresi berganda sebagai berikut. Persamaan regresi tersebut mempunyai makna: (1) Koefisien $X_{1}$ (luas lahan) = 1,013, jika luas lahan mengalami peningkatan sebesar $1 \%$, sementara modal

\section{HASIL DAN PEMBAHASAN}

Hasil Analisis Regresi Linier Berganda

Hasil analisis regresi linier berganda untuk mengetahui besarnya pengaruh variabel luas lahan $\left(\mathrm{X}_{1}\right)$, modal $\left(\mathrm{X}_{2}\right)$, dan tenaga kerja $\left(\mathrm{X}_{3}\right)$ terhadap produksi jagung di Desa Losso Kecamatan Sampaga Kabupaten Mamuju (Y). Alat analisis yang digunakan adalah dengan menggunakan program SPSS for windows release 16.0. Berdasarkan perhitungan, maka diperoleh hasil pada tabel dibawah ini (Tabel 2) : 
2004). (2) Koefisien $X_{2}$ (modal) $=(0,280)$, jika modal mengalami peningkatan sebesar $1 \%$, sementara luas lahan dan tenaga kerja dianggap tetap maka akan menyebabkan kenaikan produksi jagung. Kekurangan modal bisa menyebabkan kurangnya masukan yang diberikan pada proses pertanian sehingga menimbulkan resiko kegagalan atau rendahnya hasil yang akan diterima (Daniel, 2004:21). (3) Koefisien $\mathrm{X}_{3}$ (tenaga kerja $)=(0,204)$, jika tenaga kerja mengalami peningkatan sebesar $1 \%$, sementara luas lahan dan modal dianggap tetap maka akan menyebabkan kenaikan produksi jagung. Pada Tabel diatas diperoleh nilai koefisen regresi adalah: $\mathrm{Y}=$ $0,267+1,013 X_{1}-0,280 X_{2}+0,204 X_{3}$. Skala usaha akan mempengaruhi besar dan kecilnya berapa tenaga kerja yang dibutuhkan dan pula menentukan macam tenaga kerja yang bagaimana diperlukan (Soekartawi, 2002:26).

\section{Pengujian Hipotesis}

\section{Pengujian Parsial (uji t)}

Uji parsial ini dimaksudkan untuk mengetahui apakah masing-masing variabel bebas mempunyai pengaruh terhadap variabel terikat, yaitu untuk mengetahui seberapa jauh luas lahan $\left(\mathrm{X}_{1}\right)$, modal $\left(\mathrm{X}_{2}\right)$ dan tenaga kerja $\left(\mathrm{X}_{3}\right)$ berpengaruh secara parsial terhadap produksi jagung (Y). Hasil perhitungan dengan menggunakan program SPSS versi 16.0 dapat diketahui bahwa hasil uji t untuk variabel luas lahan $\left(\mathrm{X}_{1}\right)$. Dari table diatas dapat dilihat bahwa nilai t-hitung untuk $\mathrm{X}_{1}$ (luas lahan), $\mathrm{X}_{2}$ (modal), dan $\mathrm{X}_{3}$ (tenaga kerja), secara berturut-turut adalah $4,730,-1,168$ dan 1,303. Untuk menguji apakah masing-masing variabel secara sendiri-sendiri berpengaruh nyata terhadap $\mathrm{Y}$ (produksi). Dengan taraf nilai t-tabel yang digunakan 5\% dan derajat bebas 19 atau $(5 \%, 19)$ sama dengan 2,093 , sehingga $X_{1}$ (luas lahan) berpengaruh secara nyata karena nilai t-hitung lebih besar dari pada t-tabel, sedangkan nilai $\mathrm{X}_{2}$ (modal) dan $\mathrm{X}_{3}$ (tenaga kerja) tidak berpengaruh nyata karena nilai thitungnya $-1,168 X_{2}$ dan $1,303 \quad X_{3}$, lebih kecil dari t-tabel.

Melihat significance level yang diberikan untuk masing-masing variabel $\mathrm{X}_{1}$ (luas lahan), $\mathrm{X}_{2}$ (modal), dan $\mathrm{X}_{3}$ (tenaga kerja), dari tabel diatas kita dapat lihat bahwa significance level untuk $\mathrm{X}_{1}$ (luas lahan) sama dengan 0,000 atau $\mathrm{H}_{0}$ ditolak atau $\mathrm{X}_{1}$ (luas lahan) berpengaruh secara nyata karena lebih kecil dari taraf yang di gunakan sama dengan 5\%. Sedangkan $\mathrm{X}_{2}$ (modal), dan $\mathrm{X}_{3}$ (tenaga kerja) mempunyai significance level $0,257 \mathrm{X} 2$ dan $0,208 \mathrm{X}_{3}$ yang lebih besar daripada $0,05 \quad(5 \%)$ sehingga $\mathrm{H}_{0}$ diterima atau $\mathrm{X}_{2}$ (modal), dan 
Perbal: Jurnal Pertanian Berkelanjutan

Fakultas Pertanian Universitas Cokroaminoto Palopo

$\mathrm{X}_{3}$ (tenaga kerja) tidak berpengaruh nyata

terhadap Y (produksi).

\section{Pengujian Secara Bersama (Uji F)}

Uji hipotesis secara bersama-sama (uji

F) antara variabel bebas dalam hal ini antara $\left(\mathrm{X}_{3}\right)$, dan produksi jagung $(\mathrm{Y})$. Hasil analisis secara bersama-sama berdasarkan hasil analisis dengan bantuan program SPSS for windows release 16.0 diperoleh hasil sebagai berikut (Tabel 3) :

luas lahan $\left(\mathrm{X}_{1}\right)$, modal $\left(\mathrm{X}_{2}\right)$, tenaga kerja

Tabel 3. Hasil pengujian hipotesis dengan uji bersama-sama (Uji F)

ANOVA $^{\text {b }}$

\begin{tabular}{lllllll}
\hline & Model & Sum of Squares & df & Mean Square & F & Sig. \\
\hline 1 & Regression & 25.650 & 3 & 8.550 & 71.797 & $.000^{\mathrm{a}}$ \\
& Residual & 2.263 & 19 & .119 & & \\
& Total & 27.913 & 22 & & & \\
\hline
\end{tabular}

a. Predictors: (Constant), Tenaga Kerja, Luas Lahan, Modal

b. Dependent Variable: Produksi

Pada Tabel 3 dapat dilihat bahwa nilai F-hitung sama dengan 71,797 dengan derajat bebas untuk tabel F adalah $(3,19)$. Dari tabel F $(5 \% ; 3,19)$ diperoleh nilai 3,13 sehingga karena nilai F-hitung lebih kecil daripada nilai F-tabel maka $\mathrm{H} 0$ ditolak atau $\mathrm{X}_{1}, \mathrm{X}_{2}$, dan $X_{3}$ secara bersama-sama berpengaruh nyata terhadap Y. Melihat significance level sama dengan 0,000 lebih kecil dari taraf yang di gunakan sama dengan $5 \%$ maka $\mathrm{H}_{0}$ ditolak.

\section{Uji Koefisien Determinasi $\left(\mathbf{R}_{2}\right)$}

Besarnya pengaruh luas lahan, modal, dan tenaga kerja terhadap produksi jagung di Desa Losso Kecamatan Sampaga Kabupaten Mamuju diketahui dari harga koefisien determinasi simultan $\left(\mathrm{R}_{2}\right)$ sebagai berikut:

Tabel 4. Hasil uji koefisien determinasi $\left(\mathrm{R}_{2}\right)$

Model Summary

\begin{tabular}{|c|c|c|c|c|}
\hline \multirow[b]{2}{*}{ Model } & \multirow[b]{2}{*}{$\mathrm{R}$} & \multirow[b]{2}{*}{ R Square } & Adjusted R & Std. Error of the \\
\hline & & & \multirow[b]{2}{*}{ Square } & \multirow[b]{2}{*}{ Estimate } \\
\hline & & & & \\
\hline 1 & $.959^{\mathrm{a}}$ & .919 & .906 & .345 \\
\hline
\end{tabular}

a. Predictors: (Constant), tenaga kerja, luas lahan, modal 
Berdasarkan Tabel 4 diperoleh nilai $\mathrm{R}_{2}$, nilai $\mathrm{R}$ square 0,919 dengan nilai persentase $91,9 \% \mathrm{Y}$ (produksi) menandakan model ini sangat baik.

\section{KESIMPULAN}

Berdasarkan hasil penelitian, maka dapat disimpulkan sebagai berikut :

1. Variabel luas lahan secara parsial berpengaruh secara signifikan terhadap produksi petani jagung di Desa Losso Kecamatan Sampaga Kabupaten Mamuju karena nilai probabilitasnya $0,000<0,05$ dengan hasil uji t sebesar 4.730. Dalam model regresi koefisien $X_{1}$ luas lahan diperoleh nilai 1.013, dimana setiap penambahan luas lahan sebesar $1 \%$ maka akan terjadi kenaikan hasil produksi sebesar $1.013 \%$, dengan asumsi jumlah modal dan tenaga kerja tetap.

2. Modal tidak berpengaruh secara signifikan terhadap produksi petani jagung. Hal ini dibuktikan dari hasil uji t sebesar (1.168) dengan nilai probabilitas 0,257 koefisien $\mathrm{X}_{2}$ modal sebesar $(0,280)$, yang berarti setiap penambahan modal sebesar $1 \%$ maka akan terjadi kenaikan hasil produksi sebesar $(0,280) \%$, dengan asumsi luas lahan dan tenaga kerja tetap.

3. Variabel tenaga kerja, secara parsial tidak berpengaruh secara positif dan signifikan terhadap produksi petani jagung ditunjukkan dari hasil uji t sebesar 1,303 dengan nilai probabilitas 0,208. Koefisien $\mathrm{X}_{3}$ tenaga kerja sebesar 0,204, dimana setiap penambahan tenaga kerja sebesar 1\% maka akan terjadi kenaikan hasil produksi sebesar 0,204\%, dengan asumsi luas lahan dan modal tetap.

Pengaruh luas lahan terhadap hasil produksi jagung di Desa Losso Kecamatan Sampaga Kabupaten Mamuju meningkat karena rata-rata para petani memiliki luas lahan yang berukuran $(0,50-2,00$ ha sehingga mempengaruhi produksi jagung, sedangkan modal dan tenaga kerja tidak berpengaruh secara signifikan disebabkan karena modal sebagian masyarakat di Desa Losso lebih banyak mengeluarkan modal untuk tanaman jagung dan sebagian masyarakat belum menggunakan bantuan tenaga kerja karena modal untuk membiayai tenaga kerja tersebut belum cukup.

\section{DAFTAR PUSTAKA}

Badan Pusat Statistik [BPS]. (2016). Kecamatan Sampaga Dalam Angka. BPS Kabupaten Mamuju. Mamuju.

Badan Pusat Statistik [BPS]. (2016). Maтuju Dalam Angka. Mamuju. BPS Kabupaten Mamuju. Mamuju.

Badan Pusat Statistik [BPS] Provinsi Sulawesi Barat. (2016). Provinsi Sulawesi Barat Dalam Angka 2017. BPS Sulawesi Barat. Sulawesi Barat.

Daniel, M. (2004). Pengantar Ekonomi Pertanian. PT. Bumi Aksara. Jakarta. 
Perbal: Jurnal Pertanian Berkelanjutan

Fakultas Pertanian Universitas Cokroaminoto Palopo

Rusastra, I.W. dan M. Suryadi. (2004). Ekonomi Tenaga kerja Pertanian dan Implikasinya dalam Peningkatan Produksi dan Kesejahteraan Buruh Tani. Jurnal Litbang Pertanian. Vol. 23, No.3, pp: 91-99.

Seokartawi. (2016). Analisis Usahatani. UIPress. Jakarta.
Sujarweni, V. W. \& Endrayanto, P. (2012). Statistika untuk Penelitian. Graha Ilmu. Yogyakarta.

Sugiyono. (2009). Metode Penelitian Kuantitatif, Kualitatif dan $R \& D$. Alfabeta. Bandung. 